\title{
The Geodynamic Conditions for the Generation of Adakites and Nb-Rich Basalts (NEAB) in Kamchatka
}

\author{
G. P. Avdeiko and O. V. Bergal-Kuvikas \\ Institute of Volcanology and Seismology, Far East Branch, Russian Academy of Sciences, \\ Petropavlovsk-Kamchatsky, 683006 Russia \\ e-mail:kuvikas@mail.ru \\ Received January 14, 2014
}

\begin{abstract}
An association of adakites and rocks with intraplate geochemical parameters (NEAB) is encountered in Kamchatka, even though the Pacific plate that is plunging under Kamchatka is an old (older than $93 \mathrm{Ma}$ ) and cold plate. Inspection and comparative analysis of NEAB-adakite associations in Kamchatka and elsewhere at Pacific subduction zones revealed the geodynamic settings that favor heating of oceanic crust until the crust is melted and adakites are generated. Two geodynamic settings are favorable for the process: (1) an initial period of subduction with the tip of the slab melted and (2) generation of subduction windows. Both of these settings have existed in Kamchatka for a short period of time. In eastern Kamchatka, melting affected the tip of the slab in a new subduction zone that was formed during the late Miocene, as the subduction zone was blocked beneath the Sredinnyi Range as this zone jumped into its present location. The NEAB-adakite association in the northern part of the Sredinnyi Range was also formed in the tip of the slab that was part of the near-Commander-Islands plate. Geological sections were modeled to study conditions for the generation of NEAB-adakite associations in Kamchatka on the background of the ongoing geodynamic evolution.
\end{abstract}

DOI: $10.1134 / \mathrm{S} 0742046315050024$

\section{INTRODUCTION}

Adakite is a comparatively recent term; it was proposed by M.J. Defant and M.S. Drummond (1990) to refer to acidic and intermediate rocks (dacites and andesites) that were generated during direct melting of a comparatively young (younger than $25 \mathrm{Ma}$ ) oceanic crust. Adakites possess definite geochemical parameters, with the most pronounced among these being high $\mathrm{Sr} / \mathrm{Y}$ and $\mathrm{La} / \mathrm{Yb}$ ratios and low concentrations of $\mathrm{Y}(\leq 1.9 \mathrm{ppm})$ and $\mathrm{Yb}(\geq 18 \mathrm{ppm}$ ) (Defant and Drummond, 1990; Peacock et al., 1994; Castillo, 2006). The problem of the possible melting of oceanic crust was under lively debate during the early years of the subduction-model theory. Subsequently, it was found that the genesis of volcanic rocks at island arcs and active continental margins, that is, in subduction zones, is due to the melting of peridotite in the mantle wedge when metamorphosed by a fluid from the subducted slab (Gill, 1981; Tatsumi et al., 1986, among many others). This model has been verified for nearly all subduction zones, including the Kuril-Kamchatka island arc (Avdeiko, 1994; Volynets, 1994).

Following the publication of (Defant and Drummond, 1990), many new researchers reported adakite findings in other subduction zones, as well as the discovery of rocks with adakite geochemical characteristics in structures that are different from subduction zones. P.R. Castillo (2006) provided a rather complete review of these rocks. The locations where adakites have been dis- covered at subduction zones along the circum-Pacific rim are shown in Fig. 1. Many of these are in subduction zones whose oceanic crust is older than $25 \mathrm{Ma}$. For example, the Pacific plate around Adak Island in the Aleutians (the term "adakite" was coined from the name of this island) is approximately $52 \mathrm{Ma}$, but reliable information is available from this location concerning adakite generation due to the melting of oceanic crust (Kay, 1978; Yogodzinski and Kelemen, 1998). The age of the same plate where it is subducted under eastern Kamchatka with the known presence of adakites (Hoernle et al., 2009) exceeds $93 \mathrm{Ma}$ (Syracuse et al., 2010). It is quite obvious that rock generation due to the melting of a cold plate older than 93 Ma requires an additional source of heat.

S.M. Peacock et al. (1994) evaluated the conditions under which a subducted oceanic crust undergoes partial melting that leads to adakite generation. The evaluation of these conditions was based on experiments related to the melting of basaltic systems incorporating thermal models of subduction zones. The results of numerical simulation showed that a subducted oceanic crust can melt under very limited conditions, viz., (1) at a high degree of heating due to shear stress above 1 kbars at $T \geq$ $750^{\circ} \mathrm{C}$ in reactions of fluidless partial pressure (due to amphibole dehydration) or (2) during the subduction of a young oceanic lithosphere younger than $2 \mathrm{Ma}$ at a rate of convergence equal to $10 \mathrm{~cm} / \mathrm{yr}$ and younger than $4 \mathrm{Ma}$ at a rate of $3 \mathrm{~cm} / \mathrm{yr}$. The latter requirement does not occur in 


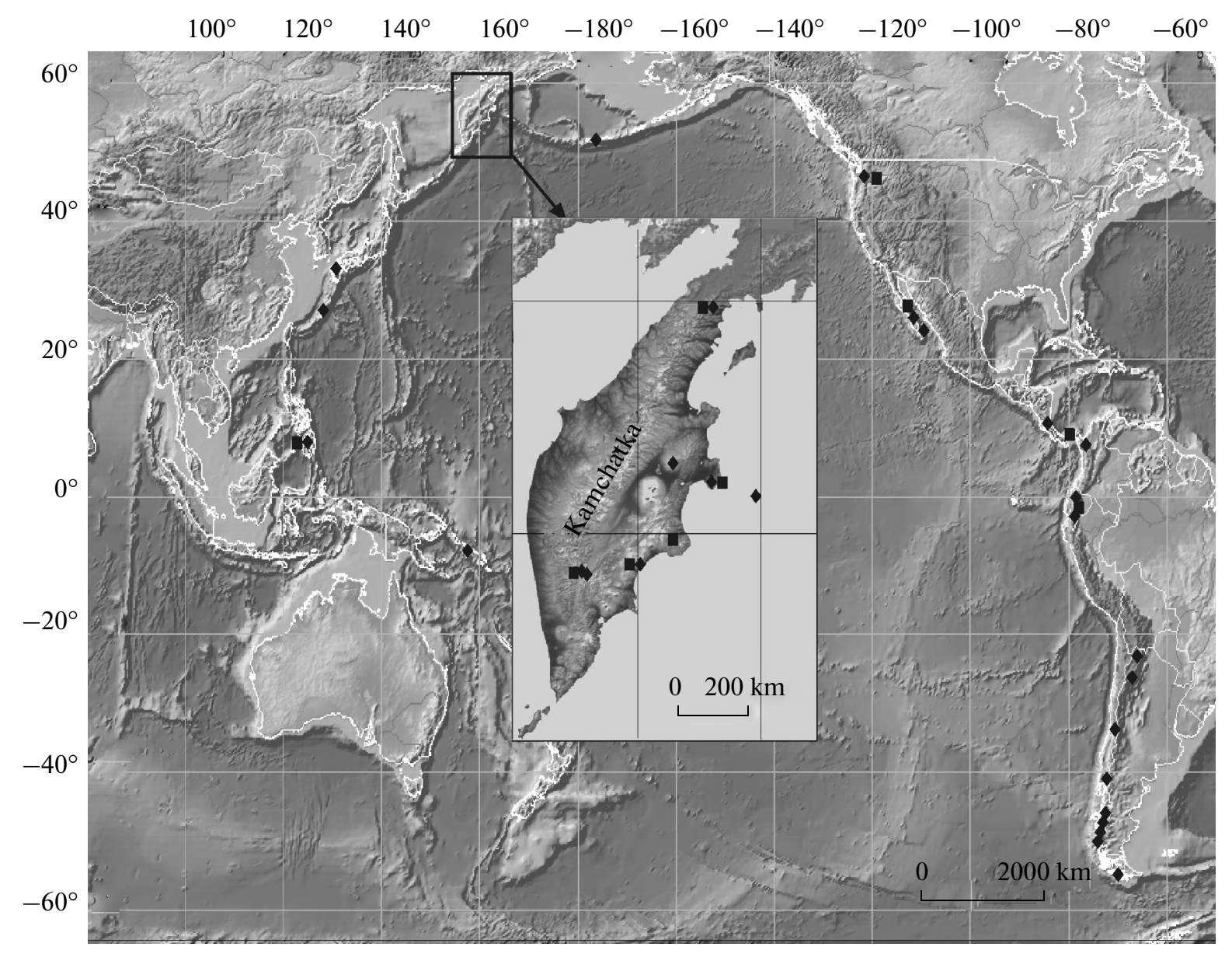

Fig. 1. Sites of adakites (diamonds) and of NEAB lavas (squares) in subduction systems along the Pacific Ring.

most of the occurrences of adakite volcanism that are shown in Fig. 1. The rate of convergence in Kamchatka is approximately $8 \mathrm{~cm} / \mathrm{yr}$ (Gorbatov and Kostoglodov, 1997). In this connection the problem of an additional source of heat for the generation of Kamchatka adakites becomes more acute than ever.

Comparison of experimental data for the melting of amphibolite and eclogite of basaltic compositions with data on the stability of plagioclase and hornblendite and on the geochemical adakite characteristics by Peacock et al. (1994) showed that an adakite melt coexists with a residual phase that contains garnet, hornblendite, and clinopyroxene, but no plagioclase, in a narrow range of pressure $(1.8-2.2 \mathrm{GPa})$ that fits depths of approximately $60-$ $70 \mathrm{~km}$, while the temperature should be at least 750$800^{\circ} \mathrm{C}$. Sen and Dunn (1994) conducted several experiments on dehydration melting to show that an amphibolite of basaltic composition at a pressure of $2.0 \mathrm{GPa}$ is melted in two stages in the $800-1100^{\circ} \mathrm{C}$ temperature range. The resulting model melt when molten to a degree of $10-15 \%$ has a composition that is identical to that of adakite, except for low values of $\mathrm{MgO}$ and $\mathrm{CaO}$. As well, the model melts do not have high $\mathrm{Sr} / \mathrm{Y}$ ratios. The authors have come to the conclusion that if adakites are generated via partial melting of a slab, they must largely interact with mantle wedge rocks or with the crust. According to experimental evidence (Rapp et al., 1999), enrichment in Mg occurs when an adakite melt reacts with the mantle wedge peridotite. The composition of the ultimate melt depends on the ratio between the adakite melt and peridotite. When this ratio is $2: 1$ and the pressure is $3.8 \mathrm{GPa}$, the ultimate melt will be rich in $\mathrm{Mg}$ and will effuse as magnesian andesites.

It should be noted that there is some evidence for the generation of rocks with adakite characteristics, not only due to the melting of a subducted oceanic crust, but also resulting from the melting of water-rich basalts in continental crust (Arculus et al., 1999; Castillo, 2006).

It should be stressed that subduction zones frequently contain basalts in association with adakites; these basalts have similar geochemical characteristics to the OIB (Oceanic Island Basalt) type. They differ from the IAB (Island Arc Basalt) type in having comparatively high concentrations of $\mathrm{Nb}$ and Ta. The rock/MORB (MidOceanic Ridge Basalt) or rock/undepleted-mantle spider diagrams exhibit a low $\mathrm{Ta}-\mathrm{Nb}$ minimum or none at all. 
These basalts have been given a variety of names: NEB, high Nb basalt, NEAB (Nobium enriched arc basalt), etc. (Castillo et al., 2007). In Kamchatka, adakites and magnesian adakites with adakite-similar characteristics are also encountered in association with $\mathrm{Nb}$ and $\mathrm{Ta}$ rich basalts. We are only concerned with the adakites that result from slab melting. The goal of the present study is to evaluate the geodynamic conditions for adakite generation at subduction zones in Kamchatka and in the Kamchatka-Aleutian junction. With this purpose in mind, we will provide a critical review of the current concepts concerning the conditions that favor the generation of adakites and NEAB at the subduction zones along the circumPacific rim, consider the geodynamic evolution of Kamchatka and the conditions that ensure the heating of an old and, accordingly, cold Pacific plate, and the melting of it. This forms a basis from which to start to propose a geodynamic model for the generation of adakites and NEAB at subduction zones of Kamchatka and the KamchatkaAleutians junction.

\section{A REVIEW OF CONCEPTS THAT CONCERN THE ORIGIN OF SUBDUCTION ADAKITES} ALONG THE CIRCUM-PACIFIC RIM

Kay (1978) was the first to infer the melting of subducted oceanic crust from his studies of chemical features, mineral composition, and isotope characteristics in two rock specimens of high-magnesium andesites sampled from the Aleutian arc. One of the two specimens was sampled on Adak Island and the other was dredged from a depth of approximately $1600 \mathrm{~m}$ in the backarc zone of the Commander-Islands sector of the Aleutian arc. The Pacific plate is approximately $52 \mathrm{Ma}$ old off Adak Island (Yogodzinski and Kelemen, 1998). Kay (1978) conducted model calculations to show that his high-magnesium andesites might have been generated during partial melting of $3 \%$ eclogite and subsequent interaction of the resulting melt with the mantle wedge peridotite.

Further large-scale studies of magnesium-rich andesites at the Aleutian island arc were conducted during expeditions on board the R/V Vulkanolog on Piip undersea volcano and on seamounts in the backarc portion of the western Aleutian arc (Volynets et al., 1993). Adakite generation at the Aleutian arc is thought to be related to the formation of a subduction window during low-angle subduction (Yogodzinski and Kelemen, 1998).

Low-angle subduction also occurs in southern South America. All the six Holocene volcanic centers in the Andean Austral volcanic zone are composed of andesites and dacites with pronounced adakite characteristics. Stern and Kilian (1996) believe that the subducting oceanic crust (basalts and sediments), which recrystallized into garnet amphibolites or eclogites, could be the most likely source of these adakites. Additional heating to provide for the melting of a crust younger than 24 Ma occurs with low rates of subduction (approximately $2 \mathrm{~cm} / \mathrm{yr}$ ). The adakites of andesitic composition on Cook Island were generated under the conditions of low-angle subduction and a small degree of partial melting (2-4\%), as well as a limited interaction with the overlying mantle. The model of magma evolution further north, as far as $49^{\circ} \mathrm{N}$ where subduction occurs at a higher angle, requires the melting of a mixture of basalts and sediments, as well as interaction, not only with the overlying mantle, but also with the crust (Stern and Kilian, 1996).

A great variety of geodynamic settings that can lead to adakite generation are found within the Central American arc, where the triple junction of the Cocos, Nazca, and Caribbean plates with the Cocos Ridge subduction occurs. Johnston and Thorkelson (1997) believe a subduction window exists beneath SE Costa Rica and western Panama due to the tensile forces that are exerted by the Galapagos spreading center. Adakite generation is thought to be related to the subduction window. The presence of a subduction window is corroborated by the absence of a seismic dipping zone beneath the Caribbean plate. The adakites on the El Valle and La Yeguada volcanoes are confined to the tip of the Nazca plate, in immediate contact with the subduction window and near the contact between the Cocos plate and the same subduction window in the Talamanca Range. An exposure of rocks that are related to an OIB-type mantle source occurs between the two adakite exposures, east and west of the triple junction.

Abratis and Wörner (2001) suggest a slightly different point of view with regard to the formation of this subduction window and the associated adakites and OIB rocks based on new dating results. According to these authors, the subduction volcanism of the Central American arc related to mantle wedge melting stopped approximately $8 \mathrm{Ma}$ in connection with the collision between the Central American arc and the aseismic Cocos Ridge. This led to a lower-angle subduction, the generation of a subduction window, and to cessation of typical calc-alkaline magmatism. The generation of the subduction window explains the rapid appearance of adakites and alkaline magmatism, which is related to an entirely different source, unlike the source of calc-alkaline magmas. In their opinion, the source of the alkaline magmas is related to the Galapagos plume on the Pacific plate. These authors proposed the hypothesis that the Pacific mantle is being emplaced into the Caribbean realm through the subduction window.

Gutscher et al. (2000) analyzed data that relate to spatial and structural features of the magmatic occurrences in the Chilean and Ecuador Andes and in Costa Rica to suggest a hypothesis that purported to explain the melting of the oceanic slab along the subhorizontal part of the subduction by crustal heating. They defined three evolutionary phases: (1) high-angle subduction resulting in the formation of a narrow calc-alkaline arc above the asthenos- 
phere wedge, (2) subhorizontal subduction, which occurs at the same depth for a stretch of a few hundred kilometers and forms a wide volcanic arc where the slab is melted, and (3) the asthenospheric wedge cools in a few million years and the volcanism is at an end. This model assumes the extra heat that is needed to melt the oceanic crust comes from heating the top of the slab by the overlying asthenosphere of the mantle wedge. It should be noted that a wide volcanic arc with adakites has not been detected anywhere as yet.

We know of rocks that have adakite and NEAB characteristics within the Cascade subduction zone in North America. The St. Helens dacites have geochemical characteristics that are typical of adakites. The melting of basalt in the subducted plate is due, in the opinion of Defant and Drummond (1993), to the young age of the still hot plate that formed in the Juan de Fuca spreading zone. The depth to the top of the slab beneath Mount St. Helens is $80 \mathrm{~km}$. We call attention to the fact that adakites were formed in this location during the initial period of subduction for the Juan de Fuca plate.

Adakites and the NEAB lavas have also been found in the Philippines. The Zamboanga Pliocene to Pleistocene island arc contains both abundant basalts (less frequently basaltic andesites) with high concentrations of niobium and much less frequent adakites (Sajona et al., 1996). Viewed with regard to their location, the NEAB lavas are encountered farther into the backarc region compared with adakites. These authors considered the space-time relationships and conditions that favor the generation of adakites and niobium rich lavas in great detail in a 3D model involving three phases of evolution.

During the first phase, approximately $5 \mathrm{Ma}$ ago, following the termination of collision in central Mindanao, the young crust of the Sulu Sea began to be subducted and dehydrated, possibly along with the spreading center. In the second phase (3-4 Ma ago) the subducted crust underwent melting at depths of $75-85 \mathrm{~km}$ (in the amphibolite-eclogite transition region) due to a high heat flow. Only some part of the adakite melt reached the surface, while the rest hybridized the mantle wedge peridotite. The process involved enrichment of the mantle wedge with high field strength elements that were included in metamorphic minerals. The convection induced by subduction made the metamorphosed mantle sink to great depths during the third phase (less than $2 \mathrm{Ma}$ ago) where the metamorphic phase, mostly amphiboles, experienced a breakdown. Melting of the metamorphosed mantle wedge involved several different degrees, resulting in several types of $\mathrm{Nb}$ enriched magmas, including NEAB. In the meanwhile the subducted slab continued to dehydrate, producing fluids that were rich in elements with large-ion lithophile elements (LILE) and in light rare earth elements, but that were both depleted in $\mathrm{Nb}$. The melting of this fluid rich mantle approximately
0.4 Ma ago generated typical calc-alkaline rocks with a $\mathrm{Ta}-\mathrm{Nb}$ minimum.

In contrast to the other Japanese volcanoes that erupt typical subduction lavas, moderately potassium andesites and dacites were erupted by the Daisen, Sambe, and Aonoyama volcanoes in southwestern Japan, and whose chemical compositions were consistent with adakites (high concentrations of $\mathrm{Al}_{2} \mathrm{O}_{3}$ and $\mathrm{Sr}$, low $\mathrm{Y}$, high $\mathrm{Sr} / \mathrm{Y}$ ratios, a steep curve that depicts the distribution of rare earth elements without the Eu minimum). Morris (1995) explained adakite generation via the tip of the Philippine plate melting at depths of $75-100 \mathrm{~km}$. The fact that no seismicity is observed beneath the volcanoes gives additional support to the idea that the frontal part of the subducted plate undergoes melting.

Research in California (Baja, California) also revealed the melting of the subducted oceanic crust producing magnesium rich andesites, which were termed bajakites (Saunders et al., 1987), although there is no subduction zone at the site. This bajakite generation is explained by the above authors by subduction of the hot Guadalupe plate and the associated rift zone.

Summing up the above discussion, we may state that only in some infrequent cases can adakite generation be accounted for by the melting of a hot subducted plate near a rift zone (California and the Philippines). Adakites are also observed at the contact with subduction windows, whatever their generation conditions (the Aleutian island arc and the Central American arcs, South America). In several cases adakite generation is related to the melting of the front of a subducted plate (the Philippines and southwestern Japan).

\section{ADAKITES AND BASALTS WITH INTRAPLATE GEOCHEMICAL CHARACTERISTICS (NEAB) IN KAMCHATKA}

In Kamchatka we distinguish three volcanic belts of different ages, which are three subduction volcanic arcs (Avdeiko et al., 2006). These belts contain, apart from typical calc-alkaline arc rocks, alkaline basalts with intraplate geochemical characteristics (NEAB), high-magnesium andesites and adakites (see table) (Volynets et al., 1997; Yogodzinski et al., 1994; Kepezhinskas et al., 1996; Volynets, 1994). The first evidence of adakites in Kamchatka subduction systems was derived by P. Kepezhinskas et al. (1996) for the Kamchatka Isthmus and for the Valovayam volcanic field (VVF) (Fig. 2, site 1). Previous research revealed the presence of alkaline basalts of the NEAB type in volcanic arcs of eastern Kamchatka, the Sredinnyi Range, in western Kamchatka, and on the landward side of the Sredinnyi Range (Volynets, 1994).

The volcanic rocks in the VVB are Late Miocene to Pliocene (5-15 Ma) lava flows, cinder cones, and dikes of basalt, basaltic andesite, andesite, and adakite. All the rocks possess subduction geochemical characteristics 
The chemical composition of Kamchatka adakites

\begin{tabular}{|c|c|c|c|c|c|c|c|c|c|c|c|c|}
\hline \multirow{2}{*}{$\begin{array}{l}\text { Compo- } \\
\text { nents }\end{array}$} & \multicolumn{2}{|c|}{ E. Kamchatka ${ }^{1}$} & \multicolumn{2}{|c|}{$\begin{array}{c}\text { Cape } \\
\text { Kamchatsky² }^{2}\end{array}$} & \multicolumn{2}{|c|}{$\begin{array}{l}\text { Kamchatsky } \\
\text { Isthmus }^{3}\end{array}$} & \multicolumn{2}{|c|}{ Mt. Shiveluch ${ }^{4}$} & \multicolumn{2}{|c|}{ Mt. Bakening ${ }^{5}$} & \multicolumn{2}{|c|}{$\mathrm{CKD}^{6}$} \\
\hline & 139 & 141 & 7616 & 7618 & VAL4 & VAL29 & $7452-1$ & 7515 & BAK 25 & BAK05 & 2628 & 3116 \\
\hline $\mathrm{SiO}_{2}$ & 58.37 & 56.10 & 57.07 & 58.43 & 57.68 & 57.76 & 62.65 & 63.48 & 60.34 & 62.52 & 57.59 & 58.32 \\
\hline $\mathrm{TiO}_{2}$ & 0.64 & 0.71 & 0.61 & 0.60 & 1.23 & 0.90 & 0.51 & 0.48 & 0.83 & 0.55 & 1.08 & 1.09 \\
\hline $\mathrm{Al}_{2} \mathrm{O}_{3}$ & 15.52 & 15.19 & 16.75 & 17.86 & 16.65 & 17.68 & 16.65 & 16.49 & 17.40 & 17.34 & 17.01 & 16.24 \\
\hline $\mathrm{FeO}$ & 5.26 & 5.73 & 3.16 & 2.24 & 7.33 & 6.86 & 4.45 & 4.28 & 3.49 & 2.50 & 1.08 & 1.40 \\
\hline $\mathrm{MnO}$ & 0.09 & 0.10 & 0.10 & 0.07 & 0.10 & 0.12 & 0.09 & 0.09 & 0.11 & 0.10 & 0.09 & 0.10 \\
\hline $\mathrm{MgO}$ & 6.82 & 8.98 & 5.68 & 4.13 & 4.82 & 3.98 & 3.49 & 3.32 & 2.11 & 1.25 & 3.77 & 4.00 \\
\hline $\mathrm{CaO}$ & 5.75 & 6.16 & 3.76 & 4.10 & 7.54 & 7.65 & 5.64 & 5.38 & 5.33 & 4.71 & 6.56 & 6.71 \\
\hline $\mathrm{Na}_{2} \mathrm{O}$ & 4.29 & 4.07 & 54.28 & 6.04 & 3.30 & 3.67 & 4.84 & 4.9 & 4.48 & 4.38 & 4.27 & 4.33 \\
\hline $\mathrm{K}_{2} \mathrm{O}$ & 1.33 & 1.56 & 2.17 & 2.52 & 1.09 & 1.06 & 1.24 & 1.25 & 1.77 & 1.92 & 1.55 & 1.34 \\
\hline $\mathrm{P}_{2} \mathrm{O}_{5}$ & 0.20 & 0.21 & 0.18 & 0.31 & 0.25 & 0.31 & 0.16 & 0.15 & 0.34 & 0.26 & 0.46 & 0.48 \\
\hline $\mathrm{H}_{2} \mathrm{O}$ & 0.36 & 0.13 & 1.95 & 1.59 & 1.16 & 0.77 & 0.23 & 0.16 & 0.46 & 1.07 & 0.61 & 0.84 \\
\hline Total & 98.64 & 98.95 & 99.53 & 99.67 & 99.63 & 100.31 & 99.96 & 99.98 & 98.65 & 98.60 & 100.02 & 100.04 \\
\hline Co & 27.7 & 34.2 & 21.7 & 20 & & & 19 & 15 & 14 & 5 & 25 & 23 \\
\hline $\mathrm{Cr}$ & 371 & 543 & 209 & 131 & 106 & 64 & 118 & 114 & 13 & 9 & 123 & 126 \\
\hline $\mathrm{Ni}$ & 171.1 & 271.1 & 134 & 130 & 51 & 34 & 16 & 14 & 5 & 0 & 66 & 52 \\
\hline V & 171 & 179 & 120 & 100 & 168 & 148 & 110 & 106 & 125 & 66 & 136 & 123 \\
\hline $\mathrm{Zn}$ & 61.7 & 59.1 & & & & & 52 & 54 & 73 & 61 & & \\
\hline $\mathrm{Ga}$ & 18.6 & 17.7 & & & & & 18 & 17 & 18 & 17 & & \\
\hline $\mathrm{Rb}$ & 24.0 & 26.0 & 33 & 30 & & & 24 & 26 & 35 & 41 & 24.8 & 19.2 \\
\hline $\mathrm{Ba}$ & 363 & 417 & 537 & 400 & 356 & 481 & 390 & 399 & 551 & 616 & 599 & 576 \\
\hline $\mathrm{Nb}$ & 11.0 & 11.6 & & & 7.5 & 10.3 & & & 5.4 & 4.4 & 7.1 & 7.3 \\
\hline $\mathrm{Ta}$ & 0.29 & 0.28 & & & & & & & 0.27 & 0.26 & 0.43 & 0.43 \\
\hline $\mathrm{Sr}$ & 541 & 470 & 675 & 453 & 594 & 746 & 579 & 567 & 589 & 487 & 977 & 928 \\
\hline Y & 11.1 & 13.4 & 11 & 13 & 14.4 & 14.7 & 10 & 12 & 12.5 & 12 & 14.4 & 13.2 \\
\hline $\mathrm{Zr}$ & 99.2 & 106.0 & 108 & 142 & 77.1 & 104 & 93 & 93 & 17.1 & 15.8 & 149 & 139 \\
\hline $\mathrm{Sr} / \mathrm{Y}$ & 48.7 & 35.1 & 61.4 & 34.9 & 41.3 & 50.8 & 57.9 & 47.8 & 47.12 & 40.6 & 67.9 & 70.2 \\
\hline
\end{tabular}

${ }^{1}$ (Hoernle et al., 2009), ${ }^{2}$ (Volynets et al., 1998), ${ }^{3}$ (Kepezhinskas et al., 1997), ${ }^{4}$ (Gorbach and Portnyagin, 2011), ${ }^{5}$ (Dorendorf et al., 2000), ${ }^{6}$ (Perepelov et al., 2009). CKD stands for Central Kamchatka Depression.

(Kepezhinskas et al., 1997). They are occasionally NEAB lavas that contain xenoliths of spinel peridotite and pyroxenite. The spinel peridotite contains dacite veins whose composition is that of adakites. The presence of adakite veins furnishes direct evidence of the melting of oceanic crust with subsequent emplacement of adakite melt into the mantle wedge peridotite (Kepezhinskas et al., 1996). Interaction between the melt and the mantle wedge peridotite was invoked by these authors to explain enrichment of clinopyroxenes in $\mathrm{Na}, \mathrm{Al}, \mathrm{Sr}, \mathrm{La}$, and $\mathrm{Ce}$ from peridotites with an accompanying increase in the $\mathrm{Sr} / \mathrm{Y}, \mathrm{La} / \mathrm{Yb}$, and $\mathrm{Zr} / \mathrm{Sm}$ ratios in the basalts that contain xenoliths. The interaction produces NEAB lavas (Kepezhinskas et al., 1996). Adakite generation is thought to be related, in the opinion of these authors, to the melting of a young (younger than $15 \mathrm{Ma}$ ), hence hot, oceanic plate of the Commander Islands basin (the older CommanderIslands plate). This is not sufficient, as experiments testify (Peacock et al., 1994). We believe that in this particular case, the initial period of subduction was also important, along with the young age of the subducted plate. This initial period began approximately $9 \mathrm{Ma}$ ago, considering that the oldest Valovayam rocks are $8.2 \mathrm{Ma}$ old (Kepezhinskas et al., 1997).

All the other alkaline NEAB rocks and adakites are only encountered in that segment of the Kuril-Kamchatka island arc system where the subduction zone jumped to occupy its present location during Late 


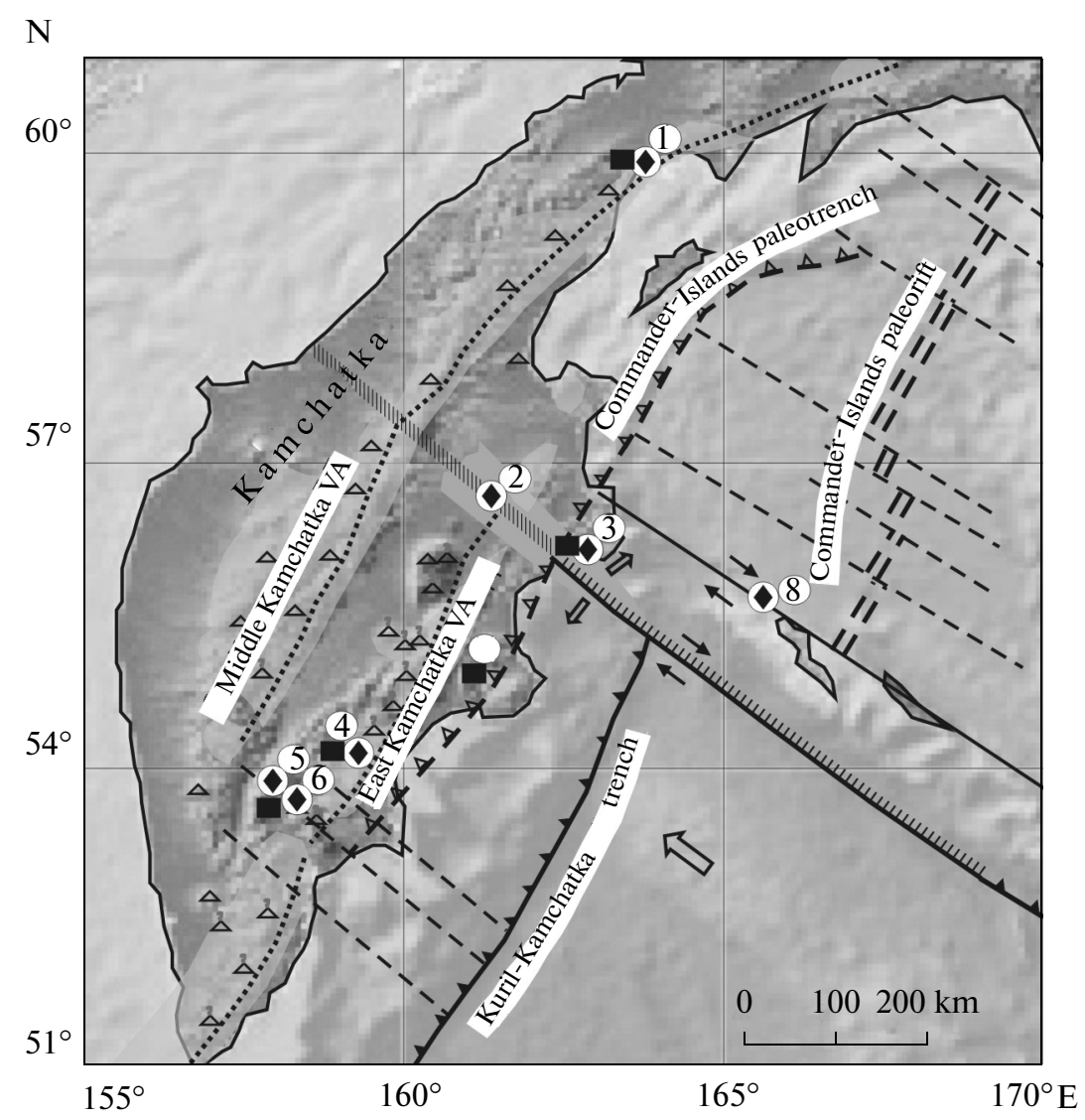

Fig. 2. Sites of adakites (diamonds) and of NEAB lavas (squares) in subduction zones along the circum-Pacific rim, in Kamchatka and the paleosubduction zones of the Commander Islands in northern Kamchatka.

The numerals on the map denote (1) Valovayam volcanic field (VVF), (2) Shiveluch Volcano, (3) Kamchatka Peninsula, (4) Levaya Zhupanova R., eastern Kamchatka, (5) unnamed volcano, (6) Bakening Volcano, (7) Kronotskii Isthmus, (8) western Aleutians, dredged rocks.

VA stands for Volcanic Arc.

Miocene time (Avdeiko et al., 2006, 2007). Syracuse et al. (2010) expressed their opinion that the age of the Pacific plate in the Kamchatka subduction zone is over $93 \mathrm{Ma}$. All the adakites in the $\mathrm{Sr} / \mathrm{Y}$ versus Y diagram (Fig. 3) as proposed by Defant and Drummond (1990) for adakite classification plot in the adakite field.

The eastern Kamchatka volcanic arc (see Fig. 2, site 4) contains, along with typical subduction series of volcanic rocks, alkaline basalts of the NEAB type, high-magnesium andesites, and adakites in the form of sills (Hoernle et al., 2009; Volynets, 1994). The widely abundant island arc rocks were formed during Late Miocene to Quaternary time, while adakites and volcanic rocks that have intraplate geochemical characteristics are sporadic and are of Late Miocene to Pliocene age, that is, they are consistent with the earlier phase in the evolution of the Eastern Kamchatka volcanic arc (Volynets, 1994). The typical calc-alkaline basalts are encountered in the upper section of the Shchapina Formation. The $\mathrm{K}-\mathrm{Ar}$ age of basalts and basanites at the bottom of the Shchapina Formation varies in the 6.8-9.12 Ma range, while a single age determination for a gabbro-syenite dike in the Valaginskii
Range gave $14.1 \pm 0.2 \mathrm{Ma}$ (Volynets et al., 1997). A new $\mathrm{Ar} / \mathrm{Ar}$ dating for the Shchapina volcanic rocks that was carried out at the IFM GEOMAR showed that the age of alkaline and transitional basalts that are enriched in light rare earth elements (LREE) and in high field strength elements varies in the 7-12 Ma range. In contrast, the age of the calc-alkaline andesites and dacites with adakite-like characteristics that occur in the top of the Shchapina Formation is 3-8 Ma (Hoernle et al., 2009).

The first evidence of the presence of alkaline volcanic rocks in eastern Kamchatka emerged from drilling operations in the Kronotskii Isthmus area (see Fig. 2, site 7). Two sills of alkaline basalts were reached in this location $\left(\mathrm{SiO}_{2}=45.80-47.16 \%\right)$, which showed high concentrations of $\mathrm{TiO}_{2}$ (up to 2.25\%) and of $\mathrm{K}_{2} \mathrm{O}$ (up to 5.5\%) (Suprunenko, 1973). These sills were confined to the bottom of flysch sand-clay deposits and contained mollusk and foraminifera fauna of Early to Middle Miocene ages.

Adakites and associated magnesian andesites and NEAB basaltoids were found in the southern Central Kamchatka Depression (see Fig. 2, site 5) within an eroded volcanic edifice whose age is $3.13-2.72 \mathrm{Ma}$ (Pere- 
pelov et al., 2009). There are small volcanic edifices that are composed of andesites and dacites around the adjacent Bakening Volcano (see Fig. 2, site 6). Their geochemical characteristics (see Fig. 3) suggest that these too can be classified as adakites. Of the 20 analyses of dacites and andesites reported by Dorendorf et al. (2000), 10 exhibit pronounced adakite characteristics $(\mathrm{Sr} / \mathrm{Y}=$ $40-283, \mathrm{La} / \mathrm{Yb}=8-16, \mathrm{Nb} / \mathrm{La}=0.2-0.3)$ and three are calc-alkaline lavas; they are transitional. These rocks are confined to a transform fault where the subduction zone jump occurs (see Fig. 2).

The first evidence of findings of adakite-type magnesian andesites in the Kamchatsky Mys Peninsula (see Fig. 2, site 3) was reported by Volynets et al. (1998). These authors identified Upper Miocene to Lower Pleistocene dikes of spessartite and vogesite $0.1-1.5 \mathrm{~m}$ thick and extending for a stretch of a few hundred meters. The dikes exhibit adakite-like characteristics that are similar to those for the adakites that are found on Adak Island. On this peninsula, Tikhomirova (1994) also found sills and dikes of alkaline basaltoids.

The magnesian andesites and dacites that were identified within the western Aleutian arc (see Fig. 2, site 8) and along the extension of the Aleutian trend (the Kamchatsky Mys Peninsula) were described in great detail by Yogodzinski et al. (1994, 1995). These authors identified two petrologic and geochemical types. The A-type magnesian adakites include the rocks that are abundant in the Kamchatsky Mys Peninsula and the rocks that were dredged between this peninsula and Bering Island. The Ptype magnesian andesites include, in addition to the rocks of Piip Volcano proper, the rocks of the Shiveluch and Zarechnyi Volcanoes. The lava dome of the active Shiveluch Volcano (see Fig. 2, site 2) also possesses adakite characteristics (Ferlito, 2011), although Gorbach and Portnyagin (2011) believe that these characteristics occur due to differentiation rather than the melting of oceanic crust.

\section{GEODYNAMIC CONDITIONS FOR ADAKITE GENERATION}

Inspection of tectonic conditions for the generation of adakites in Kamchatka and other regions of the circumPacific rim revealed some general features of the geodynamic conditions for adakite generation. In the first place, this is the initial stage of subduction in which the frontal part of the slab and the hot asthenosphere come into contact. The young age of the plunging plate furnishes an extra source of heat. Adakites of this type are typical of eastern Kamchatka, where a plate older than $93 \mathrm{Ma}$ is subducted, and of the Valovayam volcanic field (VVF) in the Kamchatsky Isthmus. The initial subduction phase in eastern Kamchatka began after the subduction zone had jumped to its present location during Late Miocene time (Fig. 4).

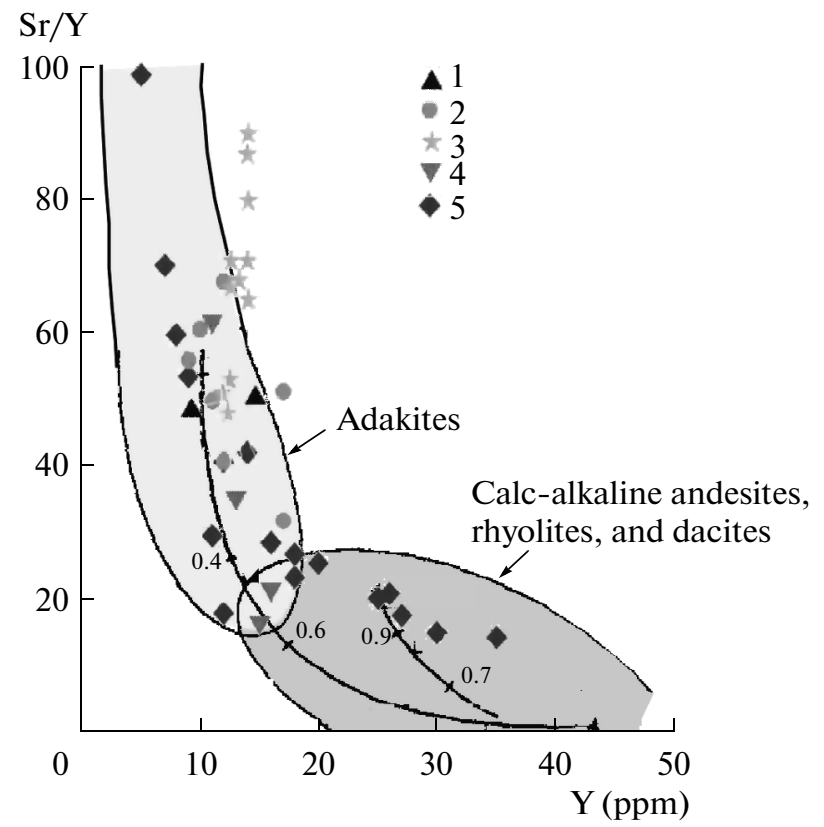

Fig. 3. The $\mathrm{Sr} / \mathrm{Y}$ vs. Y diagram for Kamchatka adakites. (1) Valovayam volcanic field (Kepezhinskas et al., 1996), (2) Levaya Zhupanova R. (Hoernle et al., 2009), (3) an unnamed volcano (Perepelov et al., 2009), (4) Kamchatsky Peninsula (Volynets et al., 1998), (5) Bakening Volcano (Dorendorf et al., 2000).

One notes the contact of the slab with the hot asthenosphere in subduction windows, whatever the conditions are of their generation.

Adakites are generally formed during a short period of time, which corresponds with experimental slab depths $(60-90 \mathrm{~km})$. The tip of the slab passes this interval during a few million years. The dehydration of amphiboles and other minerals of oceanic crust at depths greater than 90$100 \mathrm{~km}$ produces typical arc volcanic rocks of the stationary subduction regime.

Reconstruction of adakite and NEAB generation essentially involves a study of associations among these rocks. There are three types of such associations. Sometimes one observes the co-existence of adakites and NEAB within a single volcanic edifice, e.g., Mount St. Helens, the Santa Clara volcanic massif (the California Peninsula), the Kamchatsky Isthmus (VVF), and eastern Kamchatka. In other cases one observes a transverse zonality: adakites are confined to the frontal parts of arcs and the NEAB rocks are confined to the backarc region (the Mount St. Helens-Adams volcanic system in the Cascade arc, the northern volcanic zone of South America, the Philippines, etc.). In a number of cases, e.g., in the Central American arc, one notes a longitudinal zonality with NEAB rocks in the middle and adakites in the margins.

The VVF adakites (see Fig. 2, site 1) were formed at the contact between the front of the Commander-Islands slab and the hot asthenosphere of the mantle wedge 

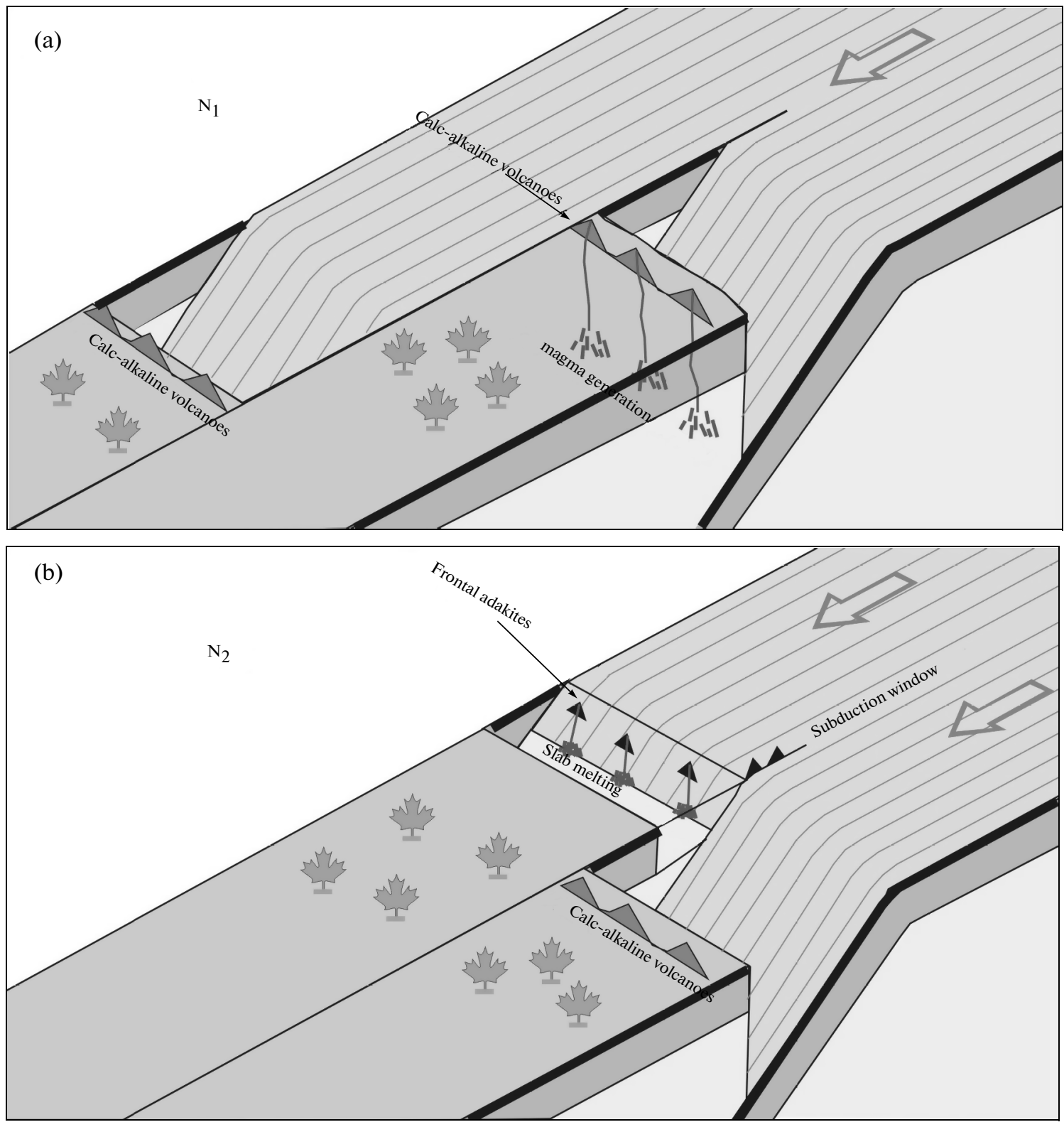

Fig. 4. A model diagram for the generation of adakites and NEAB lavas in eastern Kamchatka where the subduction zone jumped to a different location during Late Miocene time.

(a) location before the subduction zone jump, (b) the location after the jump.

(Fig. 5). The $\mathrm{Nb}$ rich arc basalts form during the melting of mantle peridotite and the mixing of these magmas with an adakite melt (Kepezhinskas et al., 1996). The short time of generation for adakites and NEAB is consistent with the above circumstance, because the plate plunges deeper than 90-100 km.

In eastern Kamchatka (see Fig. 2, site 4) where adakites and NEAB lavas were formed after the subduction jump, one observes the successive generation of "intraplate lavas," adakites, and then typical subduction lavas (Hoernle et al., 2009). The basalts in the frontal part of the subducted plate seem to melt at the contact with the hot asthenosphere (see Fig. 5). The extra heating of the sub- ducted plate is probably related to the energy of the shear and friction during the initial subduction period, and is probably also related to flexural bending and volcanism according to the model of Hirano et al. (2006). The formation of alkaline basaltic sills in the Kronotskii Isthmus (see Fig. 2, site 7) is thought (Savelyev, 2011) to be related to flexural-type volcanism; in this case this volcanism must really be of the intraplate type that was felt in the Pacific plate before it approached the subduction zone. Subsequently, these rocks were accreted to Kamchatka. This is also corroborated by their Early to Middle Miocene age based on faunistic features. 


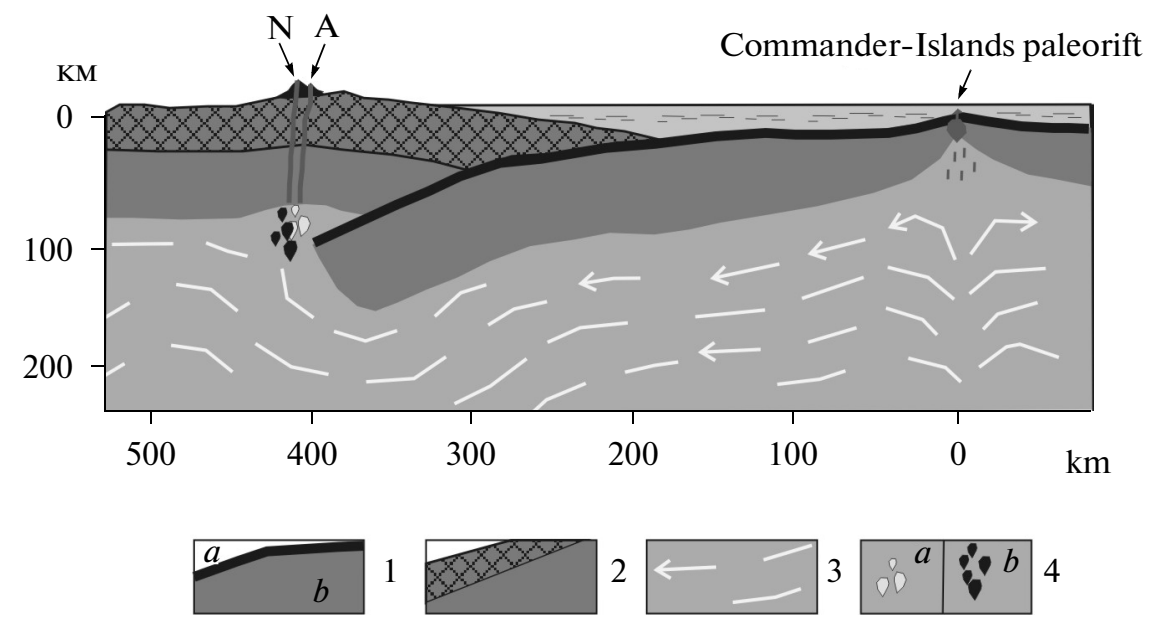

Fig. 5. A model section showing the generation of adakites and NEAB lavas in the paleo-Commander-Islands subduction zone.

(1) oceanic crust $(a)$ and the lithospheric part of the mantle $(b)$; (2) continental crust with the lithospheric part of the mantle; (3) mantle; (4) drops of adakite melt (a) and of NEAB melt (b). Legend: A stands for adakite and N for NEAB lava. For explanations, see the main text.

The adakites and NEAB basalts occupy a somewhat unusual position in the southern Central Kamchatka Depression as described by Perepelov et al. (2009). They are confined to a system of transform faults along which the subduction zone jumped to its present position in the late Miocene (see Fig. 4). We believe that the generation of these rocks was related to the formation of a subduction window during the short-lived movement of the subduction zone. The depth to the slab is at present approximately $210 \mathrm{~km}$, which is unusual. The slab may well undergo melting there in the preceding subduction zone beneath the Sredinnyi Range, with the depth to it being probably within $100 \mathrm{~km}$.

The adakite volcanism in the zone of the KamchatkaAleutian junction (see Fig. 2, sites 2, 3, and 8) seems to also be related to the formation of a subduction window and/or to the contact between the northeastern edge of the Pacific plate and the asthenosphere (Ferlito, 2011). Since the subduction window and (hence) the contact with the hot asthenosphere persist, the adakite volcanism may continue on Shiveluch Volcano. However, Gorbach and Portnyagin (2011) believe that the generation of these rocks at the location is due to differentiation.

\section{A MODEL FOR THE EVOLUTION OF SUBDUCTION VOLCANISM ALONG THE EAST KAMCHATKA VOLCANIC ARC}

The subduction volcanism within the East Kamchatka volcanic arc seems to have begun in the middle of the Miocene, since the absolute ages of the older alkaline $\mathrm{NEAB}$ basalts as found by the $\mathrm{K}-\mathrm{Ar}$ and $\mathrm{Ar}-\mathrm{Ar}$ techniques vary within 7-12 Ma (Hoernle et al., 2009; Volynets et al., 1997).

A subduction zone occurred beneath the Sredinnyi Range in the Miocene, which formed the Mid-Kam- chatka volcanic arc (Fig. 6, section 1). The section shows the continental crust of the Kronotskii intraoceanic paleoplate above the oceanic crust on the Pacific plate.

Approximately 15 Ma ago the Kronotskii arc approached the subduction zone beneath the Sredinnyi Range and began to block it (see Fig. 6, section 2). The volcanism in the Sredinnyi Range continued. As pressure was increasing on the subduction zone, a flexure-like bend began to develop on the Pacific plate after the model of Hirano et al. (2006) with the convex side in the area of the roll bulge and a synclinal depression on the Pacific side. The synclinal depression began to act on the bottom of the lithosphere, causing it to extend and to experience cracking, while the hot asthenosphere was starting to penetrate into the resulting fissures. It is immaterial whether flexural volcanism is or is not present, the lithosphere is heated in any case and thins out. Savelyev (2011) argued that the sills of alkaline basalt in the Kronotskii Isthmus were formed in this manner and were accreted to eastern Kamchatka.

The subduction under the Sredinnyi Range had been completely blocked at the end of the Middle Miocene, with an incipient subduction zone under eastern Kamchatka starting to come into being (see Fig. 6, section 3). The subduction surface of the Pacific plate was heated due to shear stresses. The blocking process ruptured the Pacific plate beneath the Sredinnyi Range, with the broken-off part of the plate sinking into the mantle, which is corroborated by seismic tomography (Gorbatov et al., 2000).

The hot front of the resulting slab reached a depth of $60-70 \mathrm{~km}$ in the time span between 7 and 9 Ma and began partial fluidless melting of metamorphosed sediments and crustal oceanic basalts at the contact with the hot asthenosphere. The resulting adakite melt penetrated into 

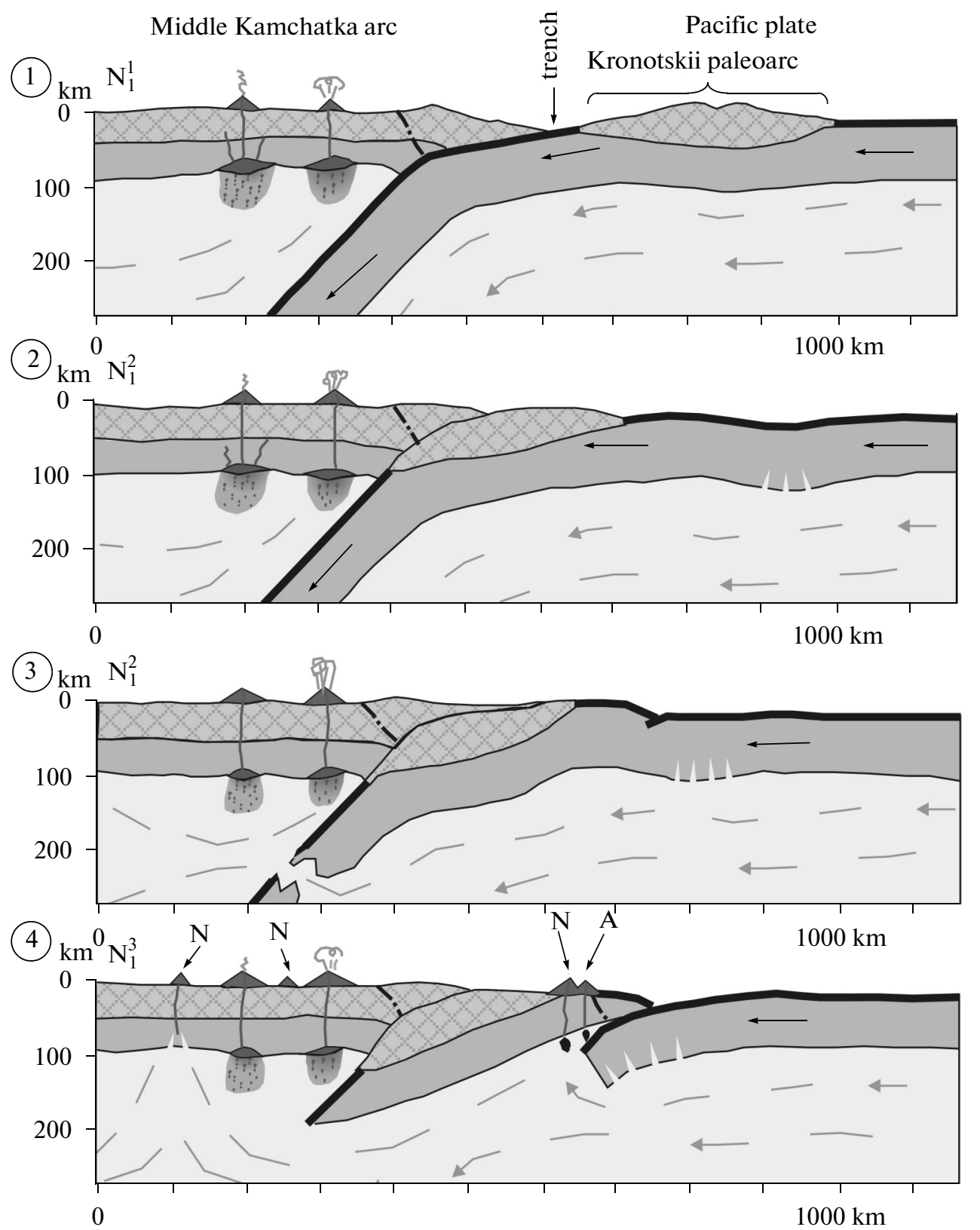

Middle Kamchatka arc East

Kamchatka arc $\frac{\overline{0}}{0}$ Pacific plate

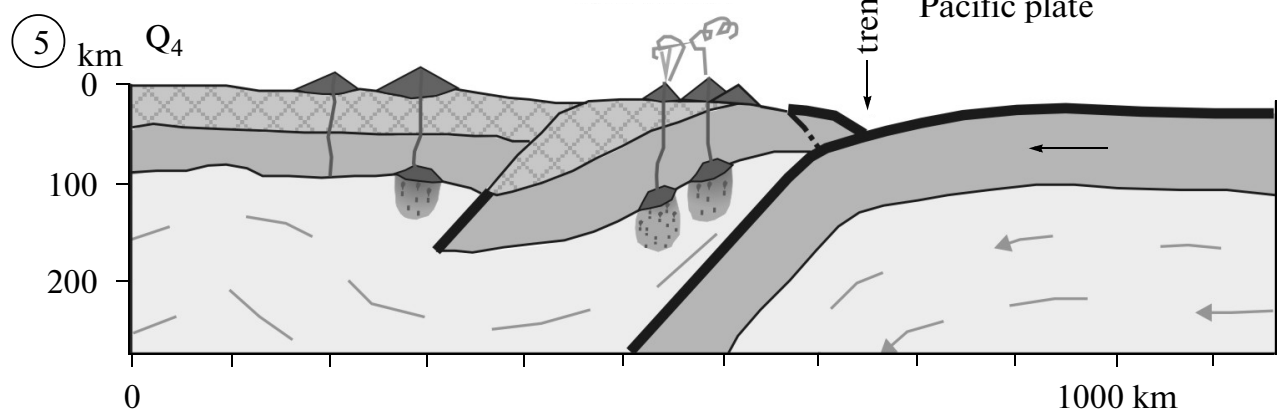

Fig. 6. Model sections that show the geodynamic evolution of the Middle-Kamchatka and East Kamchatka volcanic arcs. Legend: A stands for adakite and $\mathrm{N}$ for NEAB lava. For explanations see main text. 
the mantle wedge and interacted with peridotite in varying adakite-melt/peridotite ratios to produce magnesian andesites and $\mathrm{Nb}$ rich basalts.

At approximately the same time the subduction zone was approached by a flexure-heated part of the Pacific plate (see Fig. 6, section 4) and the movement of the heated part around the frontal part of the subduction zone formed a small mantle plume according to the Faccenna et al. (2010) model. The plume provided extra heat to melt the frontal part of the new slab and to produce a NEAB melt at low degrees of melting of the mantle plume. The two types of NEAB rock generation, viz., due to interaction with the mantle wedge peridotite and by the generation of the mantle plume, are not mutually exclusive and can occur simultaneously.

The lower edge of the remaining plate is in contact with the flow of the hot asthenosphere in the subduction zone under the Sredinnyi Range with resulting melting of the edge and generation of the NEAB type of magma (see Fig. 6, section 4).

During Pliocene and Pleistocene time the frontal edge of the Pacific plate sank to depths greater than 90-100 km and stopped melting. Typical calc-alkaline magmas began to be generated due to fluids that penetrated into the mantle wedge (see Fig. 6, section 5).

\section{CONCLUSIONS}

The above analysis of geodynamic conditions that favor adakite generation showed that, in most cases, the frontal edge of the slab undergoes melting at the contact with the hot asthenosphere during the initial period of subduction. This type of contact can take place during the initial stage of subduction and in subduction windows, whatever the origin is of the latter. The initial phase of subduction in eastern Kamchatka began after the jump from the Sredinnyi Range to the present location. Cold older plates are heated by shear stresses during the initial period of subduction zone generation.

When paleotectonic or paleovolcanic reconstructions are in question, the presence of adakites may provide evidence of subduction, especially in association with NEAB basalts.

The extra heat during the initial period of subduction can be furnished by flexural bending and by the penetration of the hot asthenosphere into fissures in the lower lithosphere and melting of it according to the model of Hirano et al. (2006).

Mantle plumes are generated at the frontal edge of the slab during the initial period of subduction according to the model of Faccenna et al. (2010).

\section{ACKNOWLEDGMENTS}

We thank the reviewers for valuable remarks and comments that led to a more accurate presentation, and A.A. Palueva for her help in the technical preparation of this publication. This work was supported by the Russian Foundation for Basic Research (East) no. 09-05-98591 and by the Far East Branch of the Russian Academy of Sciences, project no. 12-III-A-08-063.

\section{REFERENCES}

Abratis, M. and Wörner, G., Ridge collision, slab-window formation, and the flux of Pacific asthenosphere into the Caribbean realm, Geology, 2001, vol. 29, no. 2, pp. 127-130.

Arculus, R.J., Lapierre, H., and Jaillard, E., Geochemical window into subduction and accretion processes: Raspas metamorphic complex, Ecuador, Geology, 1999, vol. 27, no. 6, pp. 547-550.

Avdeiko, G.P., The geodynamics of volcanic occurrences at the Kuril island arc and evaluation of magma generation models, Geotektonika, 1994, no. 2, pp. 19-32.

Avdeiko, G.P., Palueva, A.A., and Khleborodova, O.A., Geodynamic conditions for volcanism and magma generation: The Kuril-Kamchatka island-arc system, Petrologiya, 2006, vol. 14, no. 3, pp. 248-266.

Avdeiko, G.P., Savelyev, D.P., Palueva, A.A., and Popruzhenko, S.V., Evolution of the Kurile-Kamchatkan volcanic arcs and dynamics of the KamchatkaAleutian junction, Geophysical Monograph 173: Volcanism and Subduction: the Kamchatka Region, Eichelberger, J., Gordeev, E., et al., Eds., American Geophysical Union, Washington D.C., 2007, pp. 41-60.

Castillio, P.R., An overview of adakite petrogenesis, Chinese Science Bull., 2006, vol. 51, no. 3, pp. 257-268.

Castillo, P.R., Rigby, S.J. and Solidum, R.U., Origin of high field strength element enrichment in volcanic arcs: Geochemical evidence from the Sulu Arc, southern Philippines, Lithos, 2007, vol. 97, pp. 271-288.

Defant, M.J. and Drummond, M.S., Derivation of some modern arc magmas by melting of young subducted lithosphere, Nature, 1990, vol. 347, pp. 662-665.

Defant, M.J. and Drummond, M.S., Mount St. Helens: Potential example of the partial melting of the subducted lithosphere in a volcanic arc, Geology, 1993, vol. 21, pp. 547-550.

Dorendorf, F., Churikova, T., Koloskov, A., and Wörner, G., Late Pleistocene to Holocene activity at Bakening volcano and surrounding monogenetic centers (Kamchatka): Volcanic geology and geochemical evolution, J. Volcanol. Geothermal Res., 2000, vol. 104 (1-4), pp. $131-151$.

Faccenna, C., Becker, T.W., Lallemand, S., et al., Subduction-triggered magmatic pulses: A new class of plumes? Earth. Planet. Sci. Lett., 2010, vol. 299 (1-2), pp. 5468.

Ferlito, C., Bimodal geochemical evolution at Sheveluch stratovolcano, Kamchatka, Russia: Consequence of a complex subduction at the junction of the Kuril Kamchatka and Aleutian island arcs, Earth. Sci. Rev., 2011, vol. 105 (1-2), pp. 49-69.

Gill, J.B., Orogenic Andesites and Plate Tectonics, SpringerVerlag, N.Y., 1981.

Gorbach, N.V. and Portnyagin, M.V., The geologic structure and petrology of the lava complex on Young Shiveluch Volcano, Petrologiya, 2011, vol. 19, no. 2, pp. 140172.

Gorbatov, A. and Kostoglodov, V., Maximum depth of seismicity and thermal parameter of the subducting slab: 
general empirical relation and its application, Tectonophysics, 1997, vol. 277, pp. 165-187.

Gorbatov, A., Widiyantoro, S., Fukao, Y., and Gordeev, E., Signature of remnant slabs in the North Pacific from Pwave tomography, Geophys. J. Int., 2000, vol. 142 (1), pp. 27-36.

Gutscher, M.A., Maury, R., Eissen, J.P., and Bourdon, E., Can slab melting be caused by flat subduction? Geology, 2000, vol. 28, no. 6, pp. 535-538.

Hirano, N., Takahashi, E., Yamamoto, J., et al., Volcanism in response to plate flexure, Science, 2006, vol. 313 (5792), pp. 1426-1428.

Hoernle, K., Portnyagin, M.V., Hauff, F., Van Den Bogaard, P., and Avdeiko, G., The origin of EM1 alkaline magmas during Cenozoic reorganization of subduction zone of Kamchatka, Geochim. Cosmochim Acta, 2009, vol. 73, no. 13, pp. A538-A538.

Johnston, S.T. and Thorkelson, D.J., Cocos-Nazca slab window beneath Central America, Earth Planet. Sci. Lett., 1997, vol. 146 (3-4), pp. 465-474.

Kay, R.W., Aleutian magnesian andesites-Melts from subducted Pacific Ocean crust, J. Volcanol. Geoth. Res., 1978, vol. 4 (1-2), pp. 117-132.

Kepezhinskas, P., Defant, M.J., and Drummond, M.S., Progressive enrichment of island arc mantle by meltperidotite interaction inferred from Kamchatka xenoliths, Geochim. Cosmochim. Acta, 1996, vol. 60, no. 7, pp. 1217-1229.

Kepezhinskas, P., McDermott, F., Defant, M.J., et al., Trace element and $\mathrm{Sr}-\mathrm{Nd}-\mathrm{Pb}$ isotopic constraints on a three-component model of Kamchatka arc petrogenesis, Geochim. Cosmochim. Acta, 1997, vol. 61 (3), pp. $577-600$.

Morris, P.A., Slab melting as an explanation of Quaternary volcanism and aseismicity in southwest Japan, Geology, 1995, vol. 23, no 5, pp. 395-398.

Peacock, S.M., Rushmer, T. and Thompson, A.B., Partial melting of subducting oceanic crust, Earth Planet. Sci. Lett., 1994, vol. 121 (1-2), pp. 227-244.

Perepelov, A.V., Tatarnikov, S.A., Pavlova, L.A., et al., NEB adakite volcanism in the Central Kamchatka Depression: Volcanism and geodynamics, in IV Vserossiiskii simpozium po vulkanologii $i$ paleovulkanologii. Vulkanizm i geodinamika (IV All-Russia Symp. on Volcanology and Paleovolcanology. Volcanism and Geodynamics), Proc., Petropavlovsk-Kamchatsky, 2009, vol. 2, pp. 449-454.

Rapp, R.P., Shimizu, N., Norman, M.D., and Applegate, G.S., Reaction between slab-derived melts and peridotite in the mantle wedge: Experimental constraints at $3.8 \mathrm{GPa}$, Chem. Geol., 1999, vol. 160 (4), pp. 335-356.

Sajona, F.G., Maury, R.C., Bellon, H., et al., High field strength element enrichment of Pliocene-Pleistocene island arc basalts, Zamboanga Peninsula, western Mindanao (Philippines), J. Petrol., 1996, vol. 37, no. 3, pp. 693-726.

Saunders, A.D., Rogers, G., Marriner, G.F., et al., Geochemistry of Cenozoic volcanic rocks, Baja-California, Mexico-Implications for the petrogenesis of postsubduction magmas, J. Volcanol. Geoth. Res., 1987, vol. 32 (1-3), pp. 223-245.
Savelyev, D.P., A model for precollisional genesis of alkaline basalts in the Kronotskii Isthmus, in Geologicheskie protsessy $v$ obstanovkakh subduktsii, kollizii $i$ skol'zheniya litosfernykh plit (Geological Processes in Plate Subduction, Collision, and Gliding Settings), Proc. All-Russia conference with international participation, September 20-23, 2011, Vladivostok: Dal'nauka, 2011, pp. 281-283.

Sen, C. and Dunn, T., Dehydration melting of a basaltic composition amphibolite at 1.5 and $2.0 \mathrm{Gpa-Impli-}$ cations for the origin of adakites, Contrib. Mineral. Petr., 1994, vol. 117 (4), pp. 394-409.

Stern, C.R. and Kilian, R., Role of the subducted slab, mantle wedge and continental crust in the generation of adakites from the Andean Austral volcanic zone, Contrib. Mineral. Petr., 1996, vol. 123 (3), pp. 263-281.

Suprunenko, O.I., Alkaline volcanic rocks in the Kronotskii Peninsula, Dokl. Akad. Nauk SSSR, 1973, vol. 211, no. 3, pp. 626-629.

Syracuse, E.M., van Keken, P.E., and Abers, G.A., The global range of subduction zone thermal models, Phys. Earth. Planet. Inter., 2010, vol. 183 (1-2), pp. 73-90.

Tatsumi, Y., Hamilton, D.L., and Nesbitt, R.W., Chemical characteristics of fluid phase released from a subducted lithosphere and origin of arc magmas-Evidence from high-pressure experiments and natural rocks, J. Volcanol. Geoth. Res., 1986, vol. 29 (1-4), pp. 293-309.

Tikhomirova, S.R., Late Cenozoic teschenites in eastern Kamchatka, Dokl. Akad. Nauk, 1994, vol. 335, no. 5, pp. 626-629.

Volynets, O.N., Geochemical types, petrology, and genesis of Late Genozoic volcanic rocks from the Kurile-Kamchatka island-arc system, Intern. Geol. Rev., 1994, vol. 36, pp. 373-405.

Volynets, O.N., Koloskov, A.V., Yugodzinski, G., et al., A boninite trend in the submarine lavas of Piip Volcano and its surroundings, western Aleutian arc. 1. Geology, Petrochemistry, Mineralogy, Volcanology and Seismology, 1993, vol. 14, no. 1, pp. 1-22.

Volynets, O.N., Karpenko, S.F., Koloskov, A.V., et al., The isotope composition of Late Neogene $\mathrm{K}-\mathrm{Na}$ alkaline basaltoids in eastern Kamchatka: Signatures of heterogeneities in the mantle magma source, Geokhimiya, 1997, no. 10, pp. 1005-1018.

Volynets, O.N., Ovcharenko, A.N., Boyarinova, M.E., et al., First findings of type A (Adak) magnesian andesites in Kamchatka, Geologiya i Geofizika, 1998, vol. 39, no. 11 , pp. 1153-1164.

Yogodzinski, G.M., Kay, R.W., Volynets, O.N., et al., Magnesian andesite in the western Aleutian Komandorsky region-Implications for slab melting and processes in the mantle wedge, Geol. Soc. Am. Bull., 1995, vol. 107, no. 5 , pp. 505-519.

Yogodzinski, G.M. and Kelemen, P.B., Slab melting in the Aleutians: Implications of an ion probe study of clinopyroxene in primitive adakite and basalt, Earth. Planet. Sci. Lett., 1998, vol. 158 (1-2), pp. 53-65.

Yogodzinski, G.M., Volynets, O.N., Koloskov, A.V., et al., Magnesian andesites and the subduction component in a strongly calc-alkaline series at Piip Volcano, far western Aleutians, J. Petrol., 1994, vol. 35, no. 1, pp. 163204.

Translated by A. Petrosyan 